\title{
Teologi, historie og erindring
}

\author{
Tilegnet Niels Peter Lemche på 70-årsdagen, 6. september 2015
}

Nærværende nummer af Dansk Teologisk Tidsskrift er en festskriftudgave i anledning af professor emeritus Niels Peter Lemches runde fødselsdag. Med udgangen af 2013 gik Niels Peter Lemche på pension efter at have været professor i Det Gamle Testamentes Eksegese ved Københavns Universitet siden 1987. Niels Peter Lemche begyndte sin akademiske løbebane i 1964, han blev cand.theol. fra Københavns Universitet i 1971, kandidatstipendiat i 1972 og seniorstipendiat i 1975. I årene 1978-86 var han lektor ved fakultetet i Aarhus, hvorefter han vendte tilbage til København og det førnævnte professorat efter i 1985 at have erhvervet den teologiske doktorgrad. Niels Peter Lemche har således været aktiv inden for teologien og eksegesen i rundt regnet et halvt århundrede, og hans faglige overskud og gavmildhed har haft stor betydning for kolleger og studerende ved begge de teologiske fakulteter i Danmark.

Som vejleder og underviser har Niels Peter Lemche altid været overordentlig generøs med sin tid og sin enorme viden. Semester efter semester har han organiseret læsegrupper, og derved sørget for at nye generationer af teologistuderende fik lært at læse "de andre" semitiske sprog, såsom akkadisk, ugaritisk, aramæisk og syrisk. Dette særlige engagement afspejles i nummerets første artikel, "Det syriske Adams Testamente", som er forfattet af flere af Niels Peter Lemches tidligere studerende, der har nydt godt af de semitiske læsegrupper. Artiklen er den første danske oversættelse af den ældste syriske tekstudgave af den gammeltestamentlige pseudepigraf Adams Testamente (TestAd). Oversættelsen er blevet til i et samarbejde mellem Peter Christensen, Stefan Kristensen, Amanda Norsker, Anders Larsen, Kasper Siegismund, Martin Ehrensvärd og Søren Holst, som har videreført læsegruppetraditionen ganske i Niels Peter Lemches ånd.

Flemming A.J. Nielsen gennemgår i sit bidrag fortællingerne om de to gudsmænd Elias og Elisa (1 Kong 16,29-2 Kong 13,25), og sammenligner deres praksis og mirakelhandlinger med især arktisk shamanisme. De to profeters adfærd har adskillige fællestræk med shamanistisk praksis, dog udført i et rent monoteistisk univers. Nielsen identificerer Elias' og Elisas praksis som litterær shamanisme, en alternativ form for profetisme i Det Gamle Testamente.

Jesper Høgenhaven præsenterer i sin artikel Frants Peder William Buhls (1850-1932) bibelteologiske arbejde. Buhl er især kendt som den gammeltestamentlige ekseget, der indførte den historisk-kritiske 
bibelforskning i Danmark. Buhls sammenkædning af det teologiske og eksegetiske med kirkens liv er imidlertid mindre kendt. Høgenhaven understreger den forbindelse, der ifølge Buhl består imellem en fri historisk betragtning af bibelteksterne på den ene side og forståelsen af teksterne som vidnesbyrd om en guddommelig åbenbaring på den anden.

Ingrid Hjelm tager i sit bidrag spørgsmålet om forholdet mellem den Samaritanske Pentateuk (SP) og den Masoretiske Tekst (MT) op til revision. Hjelm påpeger, at der inden for den bibelske tekstforskning er en tendens til at vurdere bibelmanuskripter i lyset af MT til trods for, at tidlige bibelfragmenter ikke synes at understøtte en opdeling i en før-masoretisk og før-samaritansk tekstfamilie.

Thomas L. Thompson evaluerer de to arkæologer William G. Dever og Israel Finkelsteins nyere forskning på baggrund af en påstand om, at de begge har distanceret sig fra såkaldt bibelsk arkæologi, dvs. en arkæologisk praksis, der bestræber sig på at finde overensstemmelser mellem arkæologiske fund og Bibelen. Thompson fremhæver tre eksempler, Salomo, Josija og landskabsarkæologi, og påpeger ud fra Devers og Finkelsteins tilgang til disse eksempler en række metodologiske problemer i de to arkæologers arbejde.

Anne Katrine de Hemmer Gudme undersøger i sit bidrag en påstand, der er blevet genfremsat af arkæologen Yitzhak Magen i forbindelse med de nyere udgravninger på Garizimbjerget, nemlig at templet på Garizim (ca. 450-110 f.Kr.) var bygget med templet i Jerusalem som forbillede. Magen hævder, at templet i Jerusalem lignede det tempel, der beskrives i Ezekiels Bog 40-48, og at templet på Garizim blev bygget som en model af dette. Gudme gennemgår de arkæologiske levn fra Garizimtemplets første byggefase (ca. 450-ca. 200 f.Kr.) og konkluderer, at der ikke er arkæologisk bevis for, at helligdommen på Garizim blev bygget med templet i Jerusalem som forbillede.

Mogens Müller tager diskussionen om Paulus' forhold til jødedommen op med fokus på Galaterbrevet 6,16, der ønsker fred og barmhjertighed for "Guds Israel". Det er omdiskuteret, om Paulus her mener det kristne gudsfolk, de jødekristne eller det jødiske folk som empirisk, etnisk størrelse. En analyse af brugen af "Israel" i de ældste kristne tekster og særligt hos Paulus leder Müller til den konklusion, at der i Galaterbrevet 6,16 må være tale om gudsfolkets troende "rest" eller det "sande Israel", dvs. de kristne.

Artiklerne i dette nummer af Dansk Teologisk Tidsskrift tilegnes Niels Peter Lemche i taknemmelighed og med de varmeste lykønskninger fra redaktion og forfattere. 